\title{
Oppression as Approached by Halqeh Mysticism
}

\author{
Mohammad Ali Taheri
}

\begin{abstract}
How should we confront oppression? According to Halqeh mysticism (Erfan-e Halqeh), we face two types of oppression; primary (inner) and secondary (apparent) oppressions. Eliminating oppression and creating justice is possible in two ways; one is to achieve justice through an external act of force, and the other, is that justice will prevail automatically as a result of the human being perceiving awareness, which will then be valuable and enduring. Today, one of the most important missions of the human being is the effort for institutionalizing the principle that in order to establish justice, one must [essentially] gain awareness; otherwise, we must accept justice based on force. If social regulations are not institutionalized, even with continuous supervision and force, the hidden perpetration of crimes and violations continues. Unless mankind perceives the truths of 'being the aspect of God', 'beauty of the Beloved', 'Unified Body', and the like, justice within the universe is unattainable.
\end{abstract}

Index Terms-Halqeh mysticism (Erfan-e Halqeh), modern slavery, oppression, qualitative judgment.

\section{INTRODUCTION (WHAT IS OPPRESSION?)}

Often, when we speak of an oppressor, nobody's finger points at oneself, and everyone considers them innocent of committing an act of oppression even though each person, at any moment, might be himself in the process of committing a serious crime, including turning a blind eye on somebody's rights, looking down at somebody, and the like. In fact, all of us commit oppression because we have no understanding of the 'face (aspect) of God'. Anywhere the 'face of God' is ignored, a portion of the universe is denied sufficient affection. In general, when one constituent [of the universe] is favoured, we neglect another constituent, and then blasphemy ${ }^{1}$ and denial of an entitlement occurs, which is in fact an act of oppression.

On the basis of this explanation, oppression has an extremely vast scope, and therefore each person must first charge himself and accuse himself of being an oppressor, and then evaluate and charge others. To eliminate oppression, our eyes must be opened to the truths [of the universe] ${ }^{2}$; and so, if yesterday, because of our closed eyes, we committed a

Manuscript received April 6, 2013; revised June 15, 2013.

Mohammad Ali Taheri is with Taman Universiti, Skudai, Johor Bahru, Malaysia (e-mail: mataheri2011@gmail.com).

${ }^{1}$ The universe is a divine manifestation and is caused by divine awareness and consciousness; therefore, human being should respect all its constituents. Desecration and covering the holiness of any constituent of the world of existence is considered "blasphemy" (Taheri, Halqeh mysticism, 2009).

${ }^{2}$ The truth of existence is the quality, the reason, and the manner of existential reality and is achievable through discovering and examining issues such as: The reason of existence and the manner of occurrence, the plan (purpose) of existence and the hidden aspects of existential reality, and the quality of existence. (For details please refer to 'Human from Another Outlook', by M.A. Taheri) oppression, now, by understanding the truth that each being in the universal existence is an 'face of God', and perceiving what that means, we will consider respect and courtesy to the divine manifestations, and distance ourselves from committing oppression. We can say that having an appearance-seeing vision of the universe is a hidden oppression that most human beings commit without being aware of it. In fact, we are born with an appearance-seeing eye and we consider that sufficient. However, each human being's duty in the universe is to, in the journey of $\mathrm{Kamal}^{3}$, turn his appearance-viewing vision into an essence-viewing vision ${ }^{4}$, and reach a point of perceiving the 'face of God' and discover that everything is God's manifestation; 'humankind shall reach a point that he cannot see anything but God ${ }^{5}$.

If this condition is not achieved, humankind has committed an oppression upon one's self, God, [the universe], and the like, because one that is incapable of perceiving the philosophy of creation will not comprehend his own mission in the universe and his position in the presence of the Creator, and by remaining ignorant about the grand design of creation, he is not only guilty of committing oppression in relationship to the universe, but also, because he cannot understand the role of others in this 'United Body' ${ }^{6}$, he commits an oppression upon them as well. Therefore, most of us are oppressors, since we cannot justify the rightfulness of our acts in respect to God and His grand plan.

Even avoiding the act of oppression or preventing it by force does not solve the problem. Because, if we do not perceive these truths, and if we remedy oppression by force, any person, in his ignorance, can commit a new oppression, and thus oppression will always exist.

\section{From IGNORANCE TO AWARENESS}

Historically, there have always been obstacles that have

\footnotetext{
${ }^{3}$ The term Kamal literally means completeness and refers to the human's spiritual growth toward completion (perfection). It includes self-realization and self-awareness, meaning clarity of vision about the universe, where we have come from and for what purpose, and where we are heading. It is attaining possessions, which are transportable to the next life, and includes the perceptions such as unity, the magnificence of the Beloved, and His presence, all of which are discussed in the book "Human from Another Outlook", M.A. Taheri.

${ }^{4}$ This is a movement from seeing appearance to seeing substance. Seeing substance is 'discovering the final Kamal of things in the universe.' When one achieves this Godly vision, one understands the grandeur of creation in every single constituent of the universe. Having substance-seeing vision reveals three aspects of everything: appearance, substance, and essence. (For details please refer to 'Human Insight', by M.A. Taheri)

${ }^{5}$ A poem by Saadi, one of the major Persian poets of the medieval period.

${ }^{6}$ The world of unity is a world that is perceptual (needs to be perceived) in which an individual perceives the Unified Body of the universe. In this perception, the universe with all its constituents is perceived as divine manifestations. Thus, individuals consider themselves in connection and unity with all universal constituents.
} 
deprived mankind from pure knowledge of the divine, and certainly those who have caused these deprivations have inflicted immense oppression on humanity. For instance, interpretations of God's words that are based upon ignorance and grudges, and do not comply with the true meaning are considered calumny against God and are the reason for the utmost oppressions in the universe.

In general, we face two kinds of oppression, 'primary (inner) oppression' and 'secondary (apparent) oppression' [1]. Primary oppression is ignorance toward God and His goals. Every lie related to God, based on ignorance or malicious intent, distances the human being from perceiving the philosophy of creation thereby causes mankind's ignorance regarding their position and duty to the Creator, the universe, one's self, and others. Human behaviour and action based on this ignorance causes another oppression which we call 'secondary oppression'. Secondary oppression is the actual outcome of this ignorance.

Now, the question arises of how we should confront oppression. Eliminating oppression and creating justice is possible in two ways; one is that justice prevails automatically in the universe as a result of humankind perceiving awareness, which is then valuable and enduring. Invitations like Imam Hussein's ${ }^{7}$ call of 'Is there anyone who can help me', is one of the most recognized calls against oppression in history, and those who have reached the necessary awareness have answered it. This invitation is bereft of the meaning and sense of extreme destitution, and creates the last opportunity for finding one's self and contemplating, an opportunity for thinking about one's own Kamal and making a decision about eliminating oppression and creating justice, which is closely related to Kamal. This message [and other similar messages in other religions and cultures] is the symbol of the 'fight against oppression' and the 'search for justice'. It is a lasting message that endures and is effective, despite the centuries that have passed since its first utterance. Such messages have been recorded in history so we can truly translate the fight against oppression.

The other way to achieve justice is through an external act of force, but this justice derived from force and dependent upon power lacks durability and the essential value. None of the messengers of God has ever committed aggression to achieve justice, because God is not the kind of ruler who would want to eliminate oppression and achieve justice through His force or coercion. Even if He were, such justice would not last.

The lesson of 'the victory of justice over the sword' is the lesson of the victory of thoughts and ideas over the sword, and it teaches us that growth and Kamal cannot be achieved with the sword, and compulsory hostile oppression will not have a lasting effect. Because each one of us is oppressive based on the level of our ignorance, and even if external oppression is removed, as long as we remain ignorant, we will remain an oppressor, and no force can change our ignorance to awareness. Thus, even if the problems of mankind are resolved through force, the roots of oppression would not be removed from the face of the Earth.

${ }^{7}$ One of Shiite imams who is famous for fighting against oppression and injustice.

\section{From SeEking Heroes to Heroism}

One of Satan's tricks for removing oppression is deceiving people's minds with a kind of thinking that we can call 'seeking heroes', which makes them believe that, without having to take action to achieve their rights, they await an hero who will regain their rights from the oppressor, and this belief has always made mankind indifferent towards achieving their rights. As a result, human society has been prevented from the thought of reaching a level of life in which they reach such awareness that no right is oppressed, and in respect for the divine manifestations, no inclination towards oppression exist. Therefore, the saving sword of mankind is 'the sword of awareness' which cuts the throat of ignorance, not the metal sword, because mankind's problem is the problem of ignorance.

Awareness brings control. Control means that, even though we have the ability to perform an act of crime, based on our awareness, we avoid it. It also means that we can commit oppression, but we choose not to. Some of our avoidance of sin is not a sign of our innocence, so are many of our avoidances of oppression that do not mean that we are not oppressors, because our opportunity to commit that sin or oppression simply did not exist. The opportunity must exist to test us so that we pass the crucial test. Only if the opportunity and the capability of committing oppression exist and we choose not to commit it, can we say that we are not oppressors, because we have consciously rejected to commit oppression.

Assume that we can, with a surgical operation on the mind of a felon, remove the possibility of his further wrong doing. Is this absence of sin valuable? Does a felon, in this way, change to an innocent person? Or is the proof of innocence in rejecting the temptation when the opportunity to commit a crime exists, meaning that he has control over his actions. Some religious acts like fasting and the like are meant to create such control, allowing us to practice the control of intentionally deciding to refrain from an act we are capable of committing [such as eating].

Achieving awareness such as perceiving the beauty of the Beloved $^{8}$, perceiving His presence ${ }^{9}$, and the like, brings mankind the ability to refrain from committing a crime based

\footnotetext{
${ }^{8}$ In the realm of Love, there is a principle that serves as a valuable yardstick for recognition of being in love: "The one in love finds the beauty and magnificence of the beloved faultless." The LeyIi and Majnoon story (an old poem from the Persian poet Nezami Ganjavi) teaches this lesson clearly to man. In the story, their love became a word of mouth and everyone assumed how beautiful Leyli must have been to have made Majnoon so crazy for her love, to such a level that he wandered about in the plains and deserts. Therefore, everybody was curious to see her, and finally the king summoned Leyli to his palace. He wanted to see her, face to face, to see the beauty that had created such a great love. However, when the king finally met Leyli he was amazed to find her quite an ordinary girl. Therefore, he told her, "Then it is you that have caused Majnoon to [madly] wander about in the deserts, but you are not prettier than the others?!" In response, Leyli unveiled the great truth: "It is the way Majnoon perceives me that has indeed caused such a passionate love and it his loving eyes that cannot see my flaws". Someone who has such eyes as Majnoon's can pass through both worlds easily as he cannot see any fault in them.

${ }^{9}$ The ardor and yearning of His lovers for His union, brings about incomprehensible exaltation. We are travelling toward God through a path that returns us to Him. In this phase of life, [the experience of] joining Him is indeed the perception of His "Presence", higher than which a human cannot experience. Therefore, while we are within our physical body, the maximum level of union with God is reaching the perception of His presence.
} 
upon his free will, not upon force and coercion. Thus, mankind's control over oppression is only possible when the monster of oppression is stopped by mankind themselves, with the chain of perceiving the 'face of God'. This is a valuable and blessed event that, if it happens in the universe, the human being will be saved. Mankind needs somebody to come and save him from ignorance, because if he is saved from ignorance, he will be able to carry out justice. Justice is born in awareness, and oppression dies in awareness as it blossoms and grows in ignorance.

\section{BASES OF JUDGMENT}

At the beginning of this paper, it was noted that anybody could, in his own position, commit a serious oppression at any moment, but now, having refuted the notion of an absolute viewpoint of oppression and oppressor and having it replaced with a relative viewpoint, we raise another question: What is the comparative significance of one oppression to another? With this comparative vision, a person who has apparently committed a small oppression (crime) could be a more devious criminal than any of the famous oppressors of history. In fact, an oppression specialist measures oppression comparatively. This is a very fine point that, from the perspective of divine justice, evaluations and judgments are qualitative and based on each person's capabilities.

For a better understanding of the meaning of qualitative judgment, we could compare Molana Rumi ${ }^{10}$ and Forough Farokhzad ${ }^{11}$. In a shallow and merely quantitative comparison between the two, most people would consider Molana Rumi more valuable, but if we judge from a qualitative perspective, we see that Molana, who had been a religious scientist, after his contact with Shams Tabrizi ${ }^{12}$, becomes the mystic Molana; whereas, Forough Farokhzad started from below the zero level, meaning from immorality, and finally reached the point where she says:

Love, since it awoke in my chest,

The demand of it overtook me, from foot to head

This is not me, is not me anymore.

Pity on the life that I lived with ' $I$ '

Thus, her growth and exaltation was more a longer journey and merits greater esteem. Of course, qualitative judgment is actually [a privilege] reserved for God. In presence of God, everyone is valued according to their own position, but mankind always judges quantitatively. Therefore, if we are asked, who is a greater oppressor -for example, history's greatest oppressors, or you?- we will answer that, certainly they are greater oppressors. But if we were put in their situation, are we confident that we would not act like or worse than they?

Additionally, a criminal's trial is based on the evidence of the crime, and in most cases wherein the sentencing is based on quantitative judgment, issues such as environment, education, complexes, and the like are not considered. Whereas, if issues were examined from a qualitative point of

\footnotetext{
${ }^{10}$ A 13th-century Persian Muslim poet, jurist, theologian, and Sufi mystic.

${ }^{11}$ A controversial Iranian modernist women poet.

${ }^{12}$ An Iranian Sufi mystic and the spiritual instructor of Rumi.
}

view, every one of us, depending upon our effectiveness on such factors, are partners in crime. A criminal is like an abscess that seems to affect only a few cells, but in truth, it has happened because of tension and involvement of many cells, and it becomes visible from the weakest part of the body. This principle is also true in social crimes. Hundreds of problems in which we are all complicit fester silently until someone commits a crime, and this crime against society usually appears at the weakest level of society from the cultural, economic and other societal points of view.

If we consider this problem from another point of view, in qualitative judgment, we have to ask a question of the person who proudly says that he has never committed theft or another crime: Have you ever suffered hunger but resisted the temptation to steal, or are you innocent only because you have always had a full stomach and not been in need? Have you ever had the opportunity to embezzle but refrained from it?

Consider whether, in a place where the standards of justice are not based on our appearance-seeing [quantity-oriented] view and its judgments and impressions, could anyone whatsoever pass the test of God's divine justice?

\section{MODERn SLAVERY}

Today, mankind is moving toward experiencing another kind of oppression, called 'modern slavery'. In this kind of slavery, human beings will decline as low as machines, and will have no mission except to be born one day and be involved in daily affairs, with their behaviour and thoughts under control, and finally exit life. In this way, mankind's sanctity, mission, and personal boundaries will be ignored more than ever before and finally be lost. This means disregarding of the step of Love ${ }^{13}$, and disregarding the human being's mission based on the consciousness of love. In such slavery, enthusiasm and eagerness, sacrifice, affection and kindness, and everything else of importance to humankind as his [distinctive] characteristics [of the phase of love] become dominated by mechanical thinking, so that no one ever asks where we have come from and where we are going to. In this situation, the spread of the destructive oppression that mankind imposes upon ourselves cannot be stopped, unless we attain awareness.

Mankind, by ignoring 'the origin of secondary oppression', has vengeful thoughts against the oppressor and unfortunately, has included God and the universe in this domain of vengeance, and slowly, this mistaken thought has rooted in some societies into the idea that the design of creation is based on [trials and] revenge, and that the Creator plans to only answer humans' mistakes with punishment. As a result, the thought of not committing sin and oppression to

\footnotetext{
${ }^{13}$ The human being is always faced with two steps: the step of wisdom and the step of Love (Eshq). The step of Love (Eshq) is the world of ecstasy and enthusiasm, wonder and surprise, attraction and fascination, sacrifice and love, and so on. It is the framework and realm called the "Tool-less (Free of Tools) World." The practical part of Halqeh mysticism takes place on the step of Love and uses no tools [technique, method and skill, advice, counsel and reasoning, endeavor and effort, and so on]. It is on this step that awareness and illumination can be achieved. The steps of Love and wisdom are correlated. (For details please refer to 'Human from Another Outlook', by M.A. Taheri)
} 
avoid God's revenge, has replaced the thought of refraining from committing oppression and sin for the purpose of attaining Kamal and exaltation. Yet, if we did not make mistakes, we would not have been in darkness, so the statement 'Moving towards light' could be meaningful. The designer of the universe (God) has declared that He will guide the eager human being from darkness to light, He takes pride in this creature that has overcome the 'darkness of ignorance' and grasped the 'light of awareness', so that it could be seen how this valuable creature has succeeded, with the help of his Creator, to escape the darkness and reach the light!

But now, what kind of thought do we have about this human being who is in darkness? Do we note that the importance [of the journey] is moving from darkness to lightness, and that the divine design was to place us in darkness in order to observe what we would do to reach the light? Hasn't the fact that God exclaimed to His angels about humankind, 'I know what you do not know', ${ }^{14}$ explained the power of the human being, which, of course, the angels could not understand?

Often, the generalities of God's intelligent design is hidden from mankind's vision by our own absolute thinking and through the tricks of the negative network ${ }^{15}$ (the Devil), which leads the mind from the direction of Kamal toward revenge and the like.

\section{Theoretical and Practical AsPects of HalQeH MYSTICISM (ERFAN-E HALQEH)}

More than three decades have passed since Dr. Mohammad Ali Taheri introduced the concept of Halqeh Mysticism (Erfan-e Halqeh) or Interuniversal Mysticism and its subdivisions, including the two fields of complementary and alternative medicines of Faradarmani and Psymentology in Iran. This doctrine that is based on pure intuitive witness-like perceptions stemming from direct insight consists of two aspects: theoretical and practical. The theoretical part necessitates discussion, study, and description to clarify where it intends to take the human being The practical aspect is made possible through establishing a link or connection (Ettesal) between human (as constituent-consciousness), and the 'Interuniversal Consciousness' or the 'Interuniversal (Cosmic) Internet' (as the whole consciousness; the collection of awareness or consciousness encompassing the universe, Divine Intelligence) [2]. Since Halqeh mysticism embraces all human beings, everybody regardless of their race, nationality, religion and personal beliefs can accept its theoretical part and make use of its practical aspect [3].

\footnotetext{
${ }^{14}$ When your lord said to the angels: 'I am placing on the earth a caliph, they replied: 'will you put there who corrupts and sheds blood, when we exalt your praises and sanctify you?' He said: 'I know what you do not know.' (Quran; Al-Baqare, 30)

${ }^{15}$ The negative network provides all the information and awareness that can distract and distance one from the path toward Kamal [Kamal-thwarting network]. Without the existence of such a hindering force, journey toward Kamal would fail to provide the necessary values, because there would be no need to exert effort or strategies to reach Kamal. And so, the human being is constantly dealing with two forces and attractions. (For details please refer to 'Human from Another Outlook', by M.A. Taheri)
}

Halqeh mysticism lays the ground-work for the unity of parts and also communication between part(s) and the whole. This is the time for fundamental reconsideration in our viewpoints and reflection upon things that have not been able to bring us wisdom and awareness of the whole in practice; like an objective observer, we must consider and analyze our faults truthfully without prejudice, to reach the perception of Kamal.

\section{CONClusion (CONSCIOUS Justice)}

Today, one of the most important missions of the human being is the effort for institutionalizing the principle that in order to establish justice, one must [essentially] gain awareness. Otherwise, we must accept justice based on force. Similarly, if social regulations are not institutionalized, even with continuous supervision and force, the hidden perpetration of crimes and violations continues, unless mankind perceives the truths of 'being the aspect of God', 'beauty of the Beloved', 'Unified Body', and the like, justice within the universe is unattainable. The day that the human being, by perceiving that each of God's creations is the 'aspect of God', realizes the sacredness of everything in the universe and no longer desires to oppress any of the elements of the universe, he will perceive the 'rank of innocence' and the meaning of 'having oppressed oneself' will become clear to him. He will be able to distance himself from sin and oppression only by freedom from ignorance, and until he reaches that stage, oppression will always be an intrinsic element of his existence. By perceiving 'qualitative justice', mankind will understand that the kindness, generosity, and benevolence of God, His ability to hear, and His mercifulness are all regulated; otherwise, the justice of God will be violated. All elements of the universe, in relation to their place, have an accountable position, which proves God's justice, and therefore there has been no oppression to the smallest particle in the universe. In case of the human being, too, God's justice prevails in a way that if we perceive it, both arguing, and more importantly, primary oppression are eliminated.

Mankind, based on our nature ${ }^{16}$, are truth seekers. Thus, we can reach the essence of the universe and, consequently avoid the apparent or secondary oppression on our own initiative. When the human being reaches the perception of his own mission, which is to discover the philosophy of creation, he realizes why he should not commit oppression. Thus, only by discovering the truth and perceiving the inner oppression can he defeat the apparent oppression. For this reason, insistence on behaviour purification without establishing inner purification, meaning creating external purification (the appearance of purification) without inner

\footnotetext{
${ }^{16}$ Nature is humankind's main software that operates similarly to the motherboard in computer hardware. Nature comprises numerous parts, which include: choice (tendency towards positive or negative), self-existence awareness software; recognition, comparison, and evaluation software, quality seeking software, adventure seeking software, motivation capability software, fundamental talents software (please refer to 'Psymentology', by M.A. Taheri)
} 
purification, will not solve mankind's problem ${ }^{17}$ [4]; however, if primary oppression is eliminated, secondary oppression inevitably cannot exist.

We can eliminate inner (primary) oppression by reaching the rank of 'the peaceful individual', which means elimination of conflict with God, one's self, the universe, and other people [5], and this is obtainable when the true face of inner oppression is discovered. In many cases throughout history, mankind, by applying the criteria of the apparent oppression, has unjustly opposed justice, and without considering the inner oppression, the Devil has been able to taint many hands with blood in which issues such as defending God's boundaries and the like have been used as different excuses. Whereas, the punishment of an individual who has inherited the cultural poverty of his ancestors and lives in ignorance and oppression is neither something to be proud of, nor the solution to any problems. We must realize that we have all been born in oppression and ignorance, and, at any moment, we can be either an oppressor or the oppressed; however, our mission requires us to be neither.

\section{REFERENCES}

[1] M. A. Taheri, A Collection of Articles, Armenia: Grigour Natoyasi, 2011, ch. 1, pp. 133

[2] M. A Taheri, Human from Another Outlook, 9th Edition, Iran: Bijan publication, 2010, ch. 2, pp. 78-95.
[3] M. A. Taheri, Halqeh Mysticism, Iran: Andisheye mandeghar, 2009, ch. 2, pp. 17.

[4] M. A. Taheri, Human and Insight, Armenia: Grigour Natoyasi, 2011, ch. 2, pp. 110-115.

[5] M. A. Taheri, Human Worldview, Iran: Tohfeh Publication, 2010, ch. 2, pp. $49-61$.

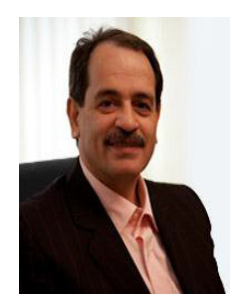

Mohammad Ali Taheri is the founder of the two Iranian complementary and alternative medicines of Faradarmani and Psymentology. He holds a BS degree in Mechanics (Turkey). After three years of research on these two C.A.M medicines, the university of traditional medicine of Armenia conferred an honorary doctorate degree in the field of complementary medicine to him (2010). The International Eco-energy Academy of the Republic of Azerbaijan also conferred upon him two honorary $\mathrm{PhD}$ degrees in complementary and alternative medicine and mysticism in two consecutive years (2009 and 2010, respectively).

Dr. Mohammad Ali Taheri has introduced Faradarmani and Psymentology and their education by publishing books and articles, attending international conference, holding educational classes, and training instructors in this science for the past two decades. Eight books and numerous articles have been published by him, and more books are being prepared for publishing (it is estimated to reach around 130 titles). The published books include: Halqeh mysticism (Iran, Andisheye Mandegar, 2009), Human from another Outlook (Iran, Bijan, 2010), Human Worldview (Iran, Tohferh, 2011), Non-organic Viruses (Armenia: Grigour Natoyasi, 2011), Human and insight (Armenia: Grigour Natoyasi, 2011), and A Collection of Articles (Armenia: Grigour Natoyasi, 2011).

\footnotetext{
${ }^{17}$ One of the important goals for one who sets foot on the path of Kamal is ethical and behavioral purification of factors regarded as anti-Kamal. If a person decides to correct his/her actions and behavior, and attempts this as a result of advice or reasoning, they will succeed in achieving 'external purification' or 'observable purification', but this purification is valuable when it results from inner or intrinsic purification. External purification, which can also be called 'behavioral purification,' is obtained by the devices of the step of wisdom and not the step of Love. However, inner purification is not possible without communication with God and by His mercy (step of Love). When people attain inner purification, their behaviors will inevitably be affected by this purification and become fundamentally corrected. (For details please refer to 'Human insight', by M.A. Taheri)
} 